\title{
Administration of Probiotics in the Water in Finfish Aquaculture Systems: A Review
}

\author{
Ladan Jahangiri ${ }^{1}$ and María Ángeles Esteban ${ }^{2, * \text { (D) }}$ \\ 1 Department of Fisheries, Faculty of Fisheries and Environmental Sciences, \\ Gorgan University of Agricultural Sciences and Natural Resources, Gorgan, Iran; \\ ladan_jahangiri@yahoo.com \\ 2 Department of Cell Biology and Histology, Faculty of Biology, Fish Innate Immune System Group, \\ Regional Campus of International Excellence “Campus Mare Nostrum”, University of Murcia, \\ 30100 Murcia, Spain \\ * Correspondence: aesteban@um.es; Tel.: +34-868887665
}

Received: 10 July 2018; Accepted: 20 August 2018; Published: 22 August 2018

\begin{abstract}
Over the last few decades, the contribution of aquaculture to animal protein production has increased enormously, and the sector now provides almost half of the fish and shellfish consumed worldwide, making it a major food producer. Nevertheless, many factors, including infections, pollution, and stress, may result in significant economic losses. The aquaculture industry will not be totally successful without the therapeutic and preventive means to control all these factors. Antibiotics (long used in aquaculture practice) have tended to aggravate the problem by increasing antibiotic resistance. Concomitantly, probiotics have widely been suggested as eco-friendly alternatives to antibiotics. However, the way in which probiotics are applied in aquaculture is a key factor in their favorable performance. The aim of this review was to examine the current state of probiotics administration through the water in finfish aquaculture. The review also attempts to cover the research gaps existing in our knowledge of this administration mode, and to suggest the issues that need to be investigated in greater depth.
\end{abstract}

Keywords: probiotics; administration method; finfish; favorable performance; aquaculture

\section{Introduction}

Aquaculture has been accelerating for decades, although outbreaks of a wide variety of infections have resulted in devastating losses economically. In contemporary aquaculture industries, the main focus has been on the use of medicines and chemical additives [1]. Due to the negative effects of chemicals and antibiotics on the environment, followed by the development of mutagenic microbial strains and adversely affected fish health, their application to control disease outbreaks is no longer recommended [2]. Therefore, the application of eco-friendly feed additives, such as microbial supplements, to improve the physiology, growth performance, and immune responses of aquaculture-related species have gained much more attention during recent years [3-5]. Naturally-occurring microorganisms play a key role in aquatic environments, as they can fulfil a wide range of roles, including recycling nutrients, degrading organic matter, and protecting fish against infections [6]. All these roles conduced to use these microorganisms in aquaculture and the development of probiotics. The use of probiotics is one of the alternative approaches to immunoprophylactic control in aquaculture $[7,8]$, and is considered a supplementary strategy or alternative to using vaccines and chemicals $[9,10]$. The definition of 'probiotic' has been modified over the years. According to the adopted definition of The Food and Agricultural Organization and World Health Organization (FAO/WHO), 'probiotics are live microorganisms that, when administered 
in adequate amounts, confer a health benefit on the host' [11]. However, according to some authors, 'probiotics applied in aquaculture are microbial cells (live or dead) or constituents of microbial cells that, when added to the water or feed, improve the general health of the host organism via improvements in the microbial balance in the environment'. Overall, probiotics are considered bio-friendly agents that can be administered in aquatic culture environments to control pathogens and enhance feed utilization, survival, and growth rate of farmed species. Furthermore, they do not have any undesirable side effects on treated organisms [12-14]. Whatever the definition, probiotics represent a new era in modern aquaculture, and both commercial and scientific interest in this topic is increasing. Indeed, nowadays, probiotics are commonly used as therapeutic and prophylactic supplements [15-20]. Lactic acid bacteria (LAB) such as some Lactobacillus species (e.g., Lactobacillus plantarum, Lactobacillus acidophilus, Lactobacillus thermophillus, Lactobacillus bulgaricus, Lactobacillus casei etc.) are frequently used as probiotics in fish nutrition [16]. The use of LAB has been shown to have the most promising effects on disease resistance, survival, and growth parameters for a wide variety of fish species [8,10,15,21-26]. However, probiotics in aquaculture encompasses a wide range of bacteria (Gram-negative or Gram-positive), yeasts, unicellular algae, and bacteriophages $[27,28]$.

It has been established in different studies that probiotics are able to produce inhibitory substances, enhance immunity, and prevent the colonization of pathogens in the gut $[15,24,29-33]$.

Management systems in aquatic and terrestrial environments are extremely different. One particular example can be the administration of drugs. There are several problems with drug applications in aquatic environments [34]. Several routes for probiotic administration are used in aquaculture systems (Figure 1). Probiotics can be administered as dietary supplements (via live food such as Artemia and rotifers or pellet food) or added to the water directly $[35,36]$. Furthermore, probiotic delivery via injection has also been reported [37]. The use of a suitable administration method contributes to the favorable performance of probiotics, and the knowledge of the action modes, along with suitable administration methods, can play a key role in their application in aquaculture [3].

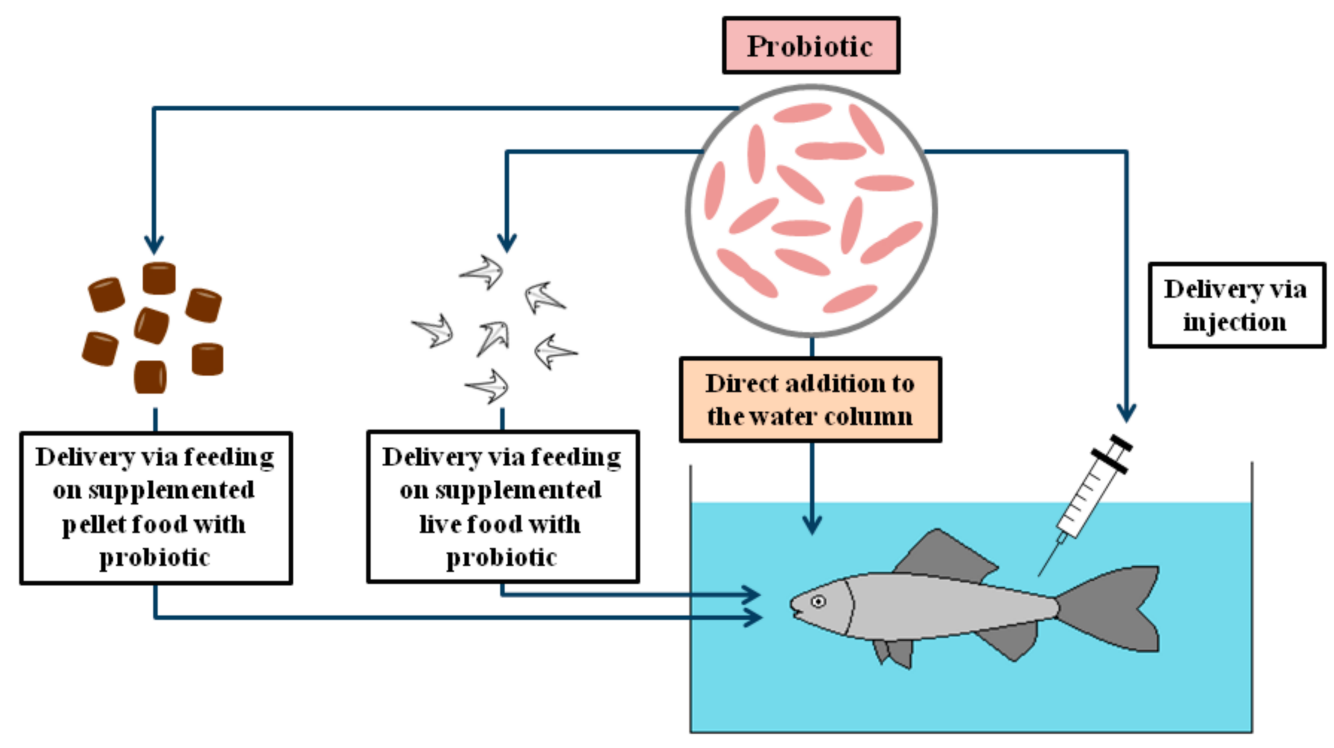

Figure 1. Different routes of probiotics administration in aquatic environment.

To date, most of the studies investigating the properties of probiotics in fish aquaculture have used dietary supplementation, and little attention has been given to possible beneficial effects of direct distribution of probiotics in water. This review summarizes our present knowledge concerning this administration method in finfish aquaculture systems. 


\section{The Range of Probiotic Administration through Water}

Among all the routes of probiotic administration in aquaculture (Figure 1), supplementation of rearing water is the only method which is applicable for all ages of fish. The administration via feeding (dry feed) definitely has limitations during early larval stages due to immature digestive tracts of fish in that stage of development. Furthermore, injection, which is not also applicable for larvae, results in a high level of stress. In contrast, direct addition of probiotics to the rearing water can be applied from the first day of hatching in incubators. The combination of probiotic administration through water and enriched live feed (especially rotifers) has been strongly recommended as the appropriate way to apply probiotics in larviculture. The commercial probiotic (Remus ${ }^{\circledR}$, Avecom, Ghent, Belgium) directly added to the water containing cod larvae (Gadus morhua L.), as well as enriched rotifers upregulated growth-related proteins and downregulated proteins related to stress [38]. According to the results, $70 \%$ of the microbial population in the intestine of cod larvae was composed of L. plantarum when the rearing water was inoculated with this probiotic bacterium [24]. Overall, administration via rearing water has been the most beneficial administration mode of probiotics in cod larviculture [18].

\section{Benefits of Probiotic Administration through Water}

According to some findings, a high level of incorporation of probiotic bacteria into treated aquatic organisms (especially in marine environments) has been observed when probiotics were administered through water compared with the levels seen using other administration protocols, perhaps because of continuous drinking in the aquatic environment [39-42].

In Table 1, the information related to different probiotics administered only through water is summarized. 
Table 1. Summary of probiotics influences on different finfish species when they were administered solely through water.

\begin{tabular}{|c|c|c|c|c|c|c|c|}
\hline Probiotics & $\begin{array}{c}\text { Biological } \\
\text { Model }\end{array}$ & Concentration & $\begin{array}{l}\text { Fish Density, Age, } \\
\text { Average Weight }\end{array}$ & $\begin{array}{l}\text { Inoculation } \\
\text { Times }\end{array}$ & $\begin{array}{c}\text { Contact } \\
\text { Duration }\end{array}$ & Major Outcomes & References \\
\hline $\begin{array}{l}\text { Lactobacillus plantarum } \\
\text { (later classified as } \\
\text { Carnobacterium divergens) }\end{array}$ & $\begin{array}{l}\text { Atlantic cod (Gadus } \\
\text { morhua L.) }\end{array}$ & $10^{5} \mathrm{CFU} \mathrm{mL}^{-1}$ & $5 \mathrm{dph}$ & - & 9 days & $\begin{array}{l}\text { Strain colonization } \\
\text { Decreased opportunistic bacteria }\end{array}$ & [24] \\
\hline Vibrio pelagius & $\begin{array}{c}\text { Turbot } \\
\text { (Scophthalmus maximus L.) }\end{array}$ & $4 \times 10^{5}$ bacteria $\mathrm{mL}^{-1}$ & $0 \mathrm{dph}$ & - & 14 days & Influenced gut microbiota & [31] \\
\hline $\begin{array}{l}\text { V. pelagius and Aeromonas } \\
\text { caviae }\end{array}$ & Turbot & $10^{5}$ bacteria $\mathrm{mL}^{-1}$ & $2-8 \mathrm{dph}$ & - & 16 days & $\begin{array}{l}\text { Colonization of probiotic bacteria in the group } \\
\text { received the bacteria at earlier days. Increased } \\
\text { survival in group received V. pelagius }\end{array}$ & [32] \\
\hline C. divergens and V. pelagius & Turbot & $10^{5}$ bacteria $\mathrm{mL}^{-1}$ & $0 \mathrm{dph}$ & & 15 days & $\begin{array}{l}\text { Higher colonization of V. pelagius. No significant } \\
\text { difference in survival }\end{array}$ & [33] \\
\hline $\begin{array}{l}\text { Enterococcus faecium ZJ4 } \\
\text { (isolated from intestinal } \\
\quad \text { tract of piglet) }\end{array}$ & $\begin{array}{l}\text { Tilapia (Oreochromis } \\
\text { niloticus) }\end{array}$ & $10^{7} \mathrm{CFU} \mathrm{mL} L^{-1}$ & $\begin{array}{l}30 \text { fishes (with average } \\
\text { weight } 6.83 \pm 0.18 \mathrm{~g} \text { ) per } \\
\text { aquarium }\end{array}$ & Every 4 days & 40 days & $\begin{array}{l}\text { Significantly higher final weight, DWG, } \\
\text { complement component } 3 \text { content, MPO activity } \\
\text { and RBA of blood phagocytes in group treated } \\
\text { with probiotic }(p<0.05) \text {. No significant difference } \\
\text { in total serum protein, albumin and globulin } \\
\text { concentration and lysozyme activity between } \\
\text { treated group and control }\end{array}$ & [43] \\
\hline $\begin{array}{l}\text { Pseudomonas sp. (isolate } \\
\text { GP21) isolated from the } \\
\text { intestine of Atlantic cod }\end{array}$ & Atlantic cod & $3.8 \times 10^{8} \mathrm{CFU} \mathrm{mL}^{-1}$ & $\begin{array}{l}8 \text { fishes (with average } \\
\text { weight } 150 \mathrm{~g} \text { ) per tank }\end{array}$ & - & $1 \mathrm{~h}$ & $\begin{array}{l}\text { Downregulated defb expression in gills and } \\
\text { upregulated defb expression in skin after treatment } \\
\text { with probiotic }\end{array}$ & [44] \\
\hline $\begin{array}{l}\text { Commercial probiotic } \\
\text { Fishery Prime } \\
\text { (Keeton Industries, } \\
\text { Wellington, CO, USA) }\end{array}$ & Perca flavescens & $5 \mathrm{~g}$ to each $100 \mathrm{~L}$ tank & $\begin{array}{l}30 \text { fishes (with average } \\
\text { weight } 6.17 \pm 2.27 \mathrm{~g} \text { ) } \\
\text { per tank }\end{array}$ & Every day & 6 weeks & $\begin{array}{l}\text { Significantly higher weight gain }(p<0.05) \text { and } \\
\text { higher levels of GH and IGF-I transcription in } \\
\text { group treated with probiotic }\end{array}$ & [45] \\
\hline Paenibacillus polymyxa & Cyprinus carpio & $\begin{array}{c}10^{3}, 10^{4} \text { and } \\
10^{5} \mathrm{CFU} \mathrm{mL} \mathrm{mL}^{-1}\end{array}$ & $\begin{array}{l}20 \text { fishes (with average } \\
\text { weight } 23.17 \mathrm{~g} \text { ) per tank }\end{array}$ & 3 times a week & 8 weeks & $\begin{array}{l}\text { Significantly improved survival, lysozyme activity, } \\
\text { MPO content, RBA, catalase and superoxidase } \\
\text { dismutase activity and resistance against } \\
\text { Aeromonas hydrophila in groups treated with } \\
\text { probiotic }(p<0.05)\end{array}$ & [46] \\
\hline Bacillus licheniformis Dahb1 & $\begin{array}{l}\text { Asian cattish } \\
\text { (Pangasius hypophthalmus) }\end{array}$ & $\begin{array}{c}10^{5} \text { and } \\
10^{7} \mathrm{CFU} \mathrm{mL}^{-1}\end{array}$ & $\begin{array}{l}12 \text { fishes (with average } \\
\text { weight } 15 \pm 2.5 \mathrm{~g} \text { ) } \\
\text { per group }\end{array}$ & - & 24 days & $\begin{array}{l}\text { Significantly higher weight gain, survival (with no } \\
\text { mortality during contact time), RBA, GST activity, } \\
\text { total glutathione activity }(p<0.05 \text { ) and higher } \\
\text { MPO and lysozyme activity in group treated with } \\
\text { probiotic. No significant difference in } \mathrm{ACH}_{50} \text { and } \\
\text { GR in group treated with probiotic }\end{array}$ & [25] \\
\hline Vibrio lentus & $\begin{array}{c}\text { Sea bass } \\
\text { (Dicentrarchus labrax) }\end{array}$ & $10^{6} \mathrm{CFU} \mathrm{mL}^{-1}$ & $\begin{array}{l}12 \text { larvae ( } 4,6 \text { and } 8 \mathrm{dph}) \\
\text { inoculated via immersion } \\
\text { in well plate }\end{array}$ & - & - & $\begin{array}{c}\text { Significantly modified gene expression (i.e., } \\
\text { immune response, cell proliferation and death, cell } \\
\text { adhesion, ROS metabolism and iron transport }(p< \\
0.05) \text {. No significant differences in apoptotic and } \\
\text { cell proliferative indexes }\end{array}$ & [47] \\
\hline
\end{tabular}

factor, dph: days post hatching, ROS: reactive oxygen species, $\mathrm{ACH}_{50}$ : serum natural complement hemolytic activity, GST: Glutathione-S-transferase, GR: reduced glutathione. 
The results obtained from this method are similar to those achieved by other administration routes. According to the published literature, probiotics as water additive could have several favorable effects on finfish aquaculture, although two main advantages have been especially emphasized: (i) the ability to control the quality of water by bioremediation, and (ii) the biocontrol of pathogens through antagonistic effects [48].

\subsection{Improvement of Water Quality}

Ammonium and nitrite, toxic metabolites originating in the feces, underused feed, and waste in aquatic systems can result in enormous economic loss [49,50], since they can affect the physiology, immunity, survival, and growth of animals [51,52]. Traditionally, toxic metabolites have been controlled by biofilters and water exchange [53-55]. Specifically, in re-circulating aquaculture systems (RAS), parameters of water quality need to be regularly controlled [56]. The zero water exchange (under sufficient management of carbon:nitrogen ratio) leads to an accumulation of organic matter and nutrients in aquaculture systems. It normally develops the microbial community, and the high diversity of microorganisms promotes the stabilization of the system by taking the nitrogen compounds which generate in situ microbial protein [57,58], improvement of nutrition [59-61], reduction of food conversion ratio (FCR), and feed costs, besides promoting the health of the organisms which are cultured [62,63]. In nature, the control of toxic compounds (ammonium and nitrogenous compounds) is potentially carried out by denitrifying bacteria; this is a role which probiotics might play. Recently, different kinds of probiotics have proven effective in ammonia nitrogen degradation. Accordingly, these eco-friendly additives can contribute to improve water quality [64]. For example, Bacillus subtilis has been widely administered as an appropriate probiotic agent to control the water quality [65]. The administration of $B$. subtilis as a water additive in the rearing water of olive flounder (Paralichthys olivaceus) resulted in significantly reduced ammonia levels and fish mortality [66]. Gram-positive bacteria, especially Bacillus spp., have been able to convert organic substances to carbon dioxide more efficiently when compared with Gram-negative bacteria converting a larger amounts of organics into bacterial biomass or slime $[12,67,68]$.

Probiotic use in the rearing water to improve water quality, and their administration to purify waste water from fish farms is helpful in areas with decreasing surface water, since the water can be reused for aquacultural activities after treatment. The probiotic bacterium Bacillus licheniformis isolated from large yellow croaker (Pseudosciaena crocea) not only significantly decreased ammonia levels, but also the starch and protein from underutilized feed in waste water [69]. A sustainable community development (SCD) study on probiotics technology for purifying waste water in ponds indicated an $85.2 \%$ decrease in ammonium nitrate concentrations, as well as a decreasing tendency in chlorophyll a levels [70]. In fact, probiotics can increase the composition of microbial species in water and improve its quality [12]. Furthermore, the higher quality of water after the addition of probiotics into aquatic environment might be because of the control of the parameters, such as dissolved oxygen, $\mathrm{pH}$, and temperature. [71,72]. However, using some probiotic species (i.e., Bacillus, Rhodopseudomonas, Nitrobacter, Cellulomonas, Pseudomonas, and Enterobacter) in the cultivation environment of channel catfish was not successful in improving water quality; consequently, except for nitrification, publications investigating the effects of probiotics on water quality are limited [1,73], and understanding of the mechanisms of action is still in its infancy [74].

\subsection{Inhibitory Activity against Fish Pathogens}

Probiotics are considered effective at strengthening innate immune responses, owing to the fact that they can interact with natural killer cells, monocytes, macrophages, and neutrophils. Their ability to enhance the number of macrophages, lymphocytes, erythrocytes, and granulocytes of a variety of fishes has been reported [27,75-79]. Dead probiotics are believed to have several advantages, as well. Such safe products can be applied to modify the biological responses [80]. Thus, probiotics can defend the host against various infections caused by pathogenic microorganisms [81]. The control of 
streptococcosis, one of the main problems in tilapia culture, has been observed as a result of enrichment of artificial feed by probiotic [82]. Although reinforcement of fish immunity and strength has been demonstrated in several studies, applied oral administration of probiotics, using probiotics as water additives is the appropriate recommended method in some specific areas:

\subsubsection{Improvement of Non-Specific Defense in Marine Fish Larvae}

Because of continuous exposures of fish skin to the aquatic environment, mucosal epithelia are considered a first-line defensive organ. A repertoire of immune cells and molecules (innate and adaptive) characterize the immune system related to mucosal epithelia of fish, governed by skin-associated lymphoid tissues, gill-associated lymphoid tissues, and gut-associated lymphoid tissues [83-88]. Marine fish larviculture has proven challenging, with high mortalities due to many complex and unknown causes; however, since the specific immune system is not completely mature during the early weeks after hatching, microorganisms may be an important cause of epizootic mortality [89-91]. Probiotic administration through incubation water can improve and stimulate the non-specific defense, as the epidermal mucus layer comprises the primary interface between larvae and the aquatic environment [29]. A significantly higher larval survival rate following the addition of the probiotic bacterium L. plantarum to the incubation water of Atlantic halibut (Hippoglossus hippoglossus L.) eggs and larvae was confirmed [91].

\subsubsection{Treatment of Fungal Infections}

Saprolegniosis, one of the major diseases in freshwater environments, is caused by fungal infections, and it can cause serious economic losses in fish farms [92,93]. Several antifungal drugs have been used to treat this disease, as mentioned in different studies. The inhibitory effect of the probiotic strain Aeromonas media A199 on Saprolegnia parasitica, which causes serious winter infection, has been shown in two fish species: eel (Anguilla australis) and silver perch (Bidyanus bidyanus), under experimental conditions [94-96]. In all of these studies, the addition of a probiotic to the water column resulted in hyphal matter release from skin into the water.

\subsubsection{Improving the Substrate Spawners Aquaculture}

To ensure a sustainable aquaculture and the safe breeding of substrate spawner species, the protection of egg clutches against pathogens is a vital necessity. Currently, no commercial therapeutics specialize in this field, especially in the case of marine species. The use of probiotics is highly promising in attempts to inhibit pathogenic infestations and decrease the mortality of larvae. Functionalized spawning tiles with probiotic Pseudoalteromonas biofilms designed for clown fish have proven to be promising candidates for the prevention of egg clutches from pathogenic infestation. Thus, probiotic application in water media can pave the way for improving the state of substrate spawners' aquaculture. Indeed, pathogenic wash out from the tiles was achieved as a result of the antagonistic effects of probiotics [97].

\section{The Major Factors Regulating the Benefits of this Administration Method}

Treatment duration (contact time), dose, and source of probiotics are important factors that can affect their activity $[2,98,99]$. However, the main factors that can affect the benefits of probiotics administration through water are outlined below.

\subsection{Temperature}

Temperature appears to be an influential factor on therapeutic activity of probiotics in aquaculture systems when they are administered through water. To exemplify this, the maximum antagonistic activity of the probiotic strain A. media A199 against saprolegniosis disease was attained with a minor water temperature increase [96]. 


\subsection{Treatment Dose}

The beneficial dose of probiotics used by direct addition to the water medium must be calculated according to the weight of the treated fishes, as well as the water volume. In a study, the effects of the commercial probiotic SA-NOLIFE MIC-F ${ }^{\circledR}$, INVE Aquaculture (Dendermonde, Belgium) (a mixture of B. licheniformis, B. subtilis and Bacillus pumilus) on growth performance and immune defense in Perca fluviatilis L. larvae were investigated. However, the administration of bacteria through water did not give rise to any significant increase in growth, survival, and immunity. It is possible that probiotic uptake by fishes with this administration mode was not sufficient to stimulate their digestive mechanisms [100]. Likewise, the direct addition of Lactobacillus spp. as a probiotic to the tank water of gilthead sea bream (Sparus aurata L.) larvae did not result in any significant increase in growth and digestive enzyme activities compared to probiotic administration in live food [101].

\subsection{Inoculation Times}

To have a stable population of probiotics at a final calculated concentration, inoculation must be renewed during treatment time. The times that the probiotic should be inoculated into the water will depend on the length of time a given probiotic takes to disappear from the water column. For this reason, this time should be calculated before the beginning of treatment.

\subsection{Age of Treated Fishes}

It has been demonstrated that probiotic administration at the earlier larval stages can modulate the gut microbiota more effectively, as the digestive tract is not completely developed, and the established microbiota reflect that of the feed and rearing water. Hence, early probiotic treatments through rearing water are strongly suggested for maximum effect. Administration of two probiotic strains (Arthrobacter sp. and Enterococcus sp.) via water column $\left(10^{5}-10^{7} \mathrm{CFU} \mathrm{mL}{ }^{-1}\right)$ at the early post-fertilization of cod could control the endogenous microbiota, and contribute to the enhancement of larval growth and survival [102].

\subsection{Salinity}

Salinity is claimed to decrease the survival of probiotic bacteria, and it may limit their application in sea-water. The half-lives of LAB in sea water $\left(35 \mathrm{~g} \mathrm{~L}^{-1}\right)$ was reported to be between 3-21 h (at $20-23^{\circ} \mathrm{C}$ ) [103]. This short duration of viability might culminate in lower colonization of probiotics in fish species inhabiting environments with higher salinities. However, in vitro and in vivo study of eight LABs, isolated from fish and seafood, as potential probiotics for turbot farming revealed that all isolates could survive in sea water for seven days (at $18{ }^{\circ} \mathrm{C}$ ) [10]. It looks as if salinity and temperature affect the beneficial effects of probiotics concomitantly. On the other hand, it must be mentioned that, in general, the direct addition of probiotics to the water column has been considered more effective than other methods in marine aquaculture [39-42].

Besides the factors outlined above, it seems as if the effects of probiotics are highly varied among various fish species [81], although there is not sufficient evidence to substantiate that.

\section{Research Gaps and Future Perspectives}

Huge benefits in aquaculture have been obtained by using probiotics as alternatives to antibiotics and chemicals, so this achievement merits more research in order to study related but less investigated issues. One of these issues is the effectiveness of different administration methods. This issue can be considered a key factor in the modern generation of probiotics in the aquaculture industry. The direct addition of probiotics into water column in aquaculture systems as a potential method has been less investigated compared to the other application methods, although some studies point to the high efficiency of probiotic administration through water. Furthermore, as this method is more effective in marine environments because of higher probiotic uptake by treated fish (on account of intensive drinking activity in these environments), more research regarding probiotics administration through 
water in different marine fish species should be carried out. Further studies in terms of environmental safety of these additives seem to be needed [104].

The least investigated issues in the field of probiotics administration as a water additive include the relationship between the quality and quantity of probiotics needed to control ammonia nitrogen in aquatic environments $[49,105]$. Likewise, despite the beneficial effects of yeasts as probiotic in finfish aquaculture, no information is available on their administration in the rearing water.

The application of different probiotics in biofloc systems has proven to be effective in the improvement of shrimp production [106,107]. To the best of our knowledge, no studies have been conducted to investigate the effects of biofloc technology combined with probiotics in finfish aquaculture.

Research into this administration route should include different molecular biotechnology tools. DNA microarrays are widely used for the evaluation of immune responses as well as dietary effects in fish $[46,108,109]$, but the information addressing transcriptomic effects stimulated by probiotics administration through water is very limited; accordingly, further studies should focus on this novel tool to gain a better understanding of the efficacy of probiotics application as a water additive.

\section{Conclusions}

Administration of therapeutics and feed additives in aquatic environments has its limitations in comparison to terrestrial habitations; that is the reason why the strategies which are applied in this area have been the topic of several studies related to aquaculture. Among these topics, finding the most effective and affordable approach has been a key focus. Probiotics as an alternative to chemicals and antibiotics have proven to be effective in promoting successful aquaculture, as they have the potential to improve water quality, increase tolerance to stress, generate high-quality livestock etc. Regarding all of these benefits, the routes of probiotic administration need to be more investigated. Our brief review suggests that the best administration method should be selected according to age and size of fish, aquaculture system, and all other contributing factors. Although the direct addition of probiotics to the water has been shown to be effective in different studies, it cannot be proposed as the best way in all cases where probiotics are used.

In conclusion, further research in the field of probiotic administration through water needs to be conducted in order to develop economically acceptable treatment practices for intensive production, always taking into account that the results may vary according to the different probiotics used.

Author Contributions: Funding acquisition, M.Á.E.; Review, L.J. and M.Á.E.; Writing—original draft, L.J.; Writing—review \& editing, L.J. and M.Á.E.

Funding: This research was partly funded by the Spanish Ministery of Economy and Competitiveness (MINECO) co-funded by the European Regional Development Funds (Grant no. AGL2014-51839-C5-1-R) and the Fundación Séneca de la Región de Murcia (Grupo de Excelencia grant no. 19883/GERM/15).

Conflicts of Interest: the authors declare no conflict of interest.

\section{References}

1. Martínez Cruz, P.; Ibáñez, A.L.; Monroy Hermosillo, O.A.; Ramírez Saad, H.C. Use of Probiotics in Aquaculture. ISRN Microbiol. 2012, 2012, 1-14. [CrossRef] [PubMed]

2. Cabello, F.C. Heavy use of prophylactic antibiotics in aquaculture: A growing problem for human and animal health and for the environment. Environ. Microbiol. 2006, 8, 1137-1144. [CrossRef] [PubMed]

3. Dawood, M.A.O.; Koshio, S. Recent advances in the role of probiotics and prebiotics in carp aquaculture: A review. Aquaculture 2016, 454, 243-251. [CrossRef]

4. Guerreiro, I.; Couto, A.; Machado, M.; Castro, C.; Pousão-Ferreira, P.; Oliva-Teles, A.; Enes, P. Prebiotics effect on immune and hepatic oxidative status and gut morphology of white sea bream (Diplodus sargus). Fish Shellfish Immunol. 2016, 50, 168-174. [CrossRef] [PubMed]

5. Song, S.K.; Beck, B.R.; Kim, D.; Park, J.; Kim, J.; Kim, H.D.; Ringø, E. Prebiotics as immunostimulants in aquaculture: A review. Fish Shellfish Immunol. 2014, 40, 40-48. [CrossRef] [PubMed] 
6. Bentzon-Tilia, M.; Sonnenschein, E.C.; Gram, L. Monitoring and managing microbes in aquaculture-Towards a sustainable industry. Microb. Biotechnol. 2016, 9, 576-584. [CrossRef] [PubMed]

7. Magnadottir, B. Immunological control of fish diseases. Mar. Biotechnol. 2010, 12, 361-379. [CrossRef] [PubMed]

8. Esteban, M.Á.; Cordero, H.; Martínez-Tomé, M.; Jiménez-Monreal, A.M.; Bakhrouf, A.; Mahdhi, A. Effect of dietary supplementation of probiotics and palm fruits extracts on the antioxidant enzyme gene expression in the mucosae of gilthead seabream (Sparus aurata L.). Fish Shellfish Immunol. 2014, 39, 532-540. [CrossRef] [PubMed]

9. Pérez-Sánchez, T.; Ruiz-Zarzuela, J.; de Blas, I.; Balcázar, J.L. Probiotics in aquaculture: A current assessment. Rev. Aquac. 2013, 6, 1-14. [CrossRef]

10. Muñoz-Atienza, E.; Araújo, C.; Magadán, S.; Hernández, P.E.; Herranz, C.; Santos, Y.; Cintas, L.M. In vitro and in vivo evaluation of lactic acid bacteria of aquatic origin as probiotics for turbot (Scophthalmus maximus L.) farming. Fish Shellfish Immunol. 2014, 41, 570-580. [CrossRef] [PubMed]

11. Food and Agricultural Organization and World Health Organization. Antimicrobial Resistance Fact Sheet 194. Available online: http:/ / www.who.int/inf-fs/en/fact194html (accessed on 7 July 2018).

12. Mohapatra, S.; Chakraborty, T.; Kumar, V.; De Boeck, G.; Mohanta, K.N. Aquaculture and stress management: A review of probiotic intervention. J. Anim. Physiol. Anim. Nutr. 2013, 97, 405-430. [CrossRef] [PubMed]

13. C. De, B.; Meena, D.K.; Behera, B.K.; Das, P.; Das Mohapatra, P.K.; Sharma, A.P. Probiotics in fish and shellfish culture: Immunomodulatory and ecophysiological responses. Fish Physiol. Biochem. 2014, 40, 921-971. [CrossRef] [PubMed]

14. Huynh, T.G.; Shiu, Y.L.; Nguyen, T.P.; Truong, Q.P.; Chen, J.C.; Liu, C.H. Current applications, selection, and possible mechanisms of actions of synbiotics in improving the growth and health status in aquaculture: A review. Fish Shellfish Immunol. 2017, 64, 367-382. [CrossRef] [PubMed]

15. Nayak, S.K. Probiotics and immunity: A fish perspective. Fish Shellfish Immunol. 2010, 29, 2-14. [CrossRef] [PubMed]

16. Nayak, S.K. Role of gastrointestinal microbiota in fish. Aquac. Res. 2010, 41, 1553-1573. [CrossRef]

17. Kiron, V. Fish immune system and its nutritional modulation for preventive health care. Anim. Feed Sci. Technol. 2012, 173, 111-133. [CrossRef]

18. Lauzon, H.L.; Pérez-Sánchez, T.; Merrifield, D.L.; Ringø, E.; Balcázar, J.L. Probiotic application in cold water fish species. In Aquaculture Nutrition: Gut Health, Probiotics and Prebiotics; Merrifield, D.L., Ringø, E., Eds.; Wiley-Blackwell Publishing: Oxford, UK, 2014; pp. 223-252.

19. Carnevali, O.; Sun, Y.Z.; Merrifield, D.L.; Zhou, Z.; Picchietti, S. Probiotic application in temperate and warm water fish species. In Aquaculture Nutrition: Gut Health, Probiotics and Prebiotics; Merrifield, D.L., Ringø, E., Eds.; Wiley-Blackwell Publishing: Oxford, UK, 2014; pp. 253-289.

20. Hoseinifar, S.H.; Ringø, E.; ShenavarMasouleh, A.; Esteban, M.Á. Probiotic, prebiotic and synbiotic supplements in sturgeon aquaculture: A review. Rev. Aquac. 2014, 6, 1-14. [CrossRef]

21. Ringø, E.; Gatesoupe, F.J. Lactic acid bacteria in fish: A review. Aquaculture 1998, 160, 177-203. [CrossRef]

22. Dawood, M.A.O.; Koshio, S.; Ishikawa, M.; Yokoyama, S.; El Basuini, M.F.; Hossain, M.S.; Nhu, T.H.; Dossou, S.; Moss, A.S. Effects of dietary supplementation of Lactobacillus rhamnosus or/and Lactococcus lactis on the growth, gut microbiota and immune responses of red sea bream, Pagrus major. Fish Shellfish Immunol. 2016, 49, 275-285. [CrossRef] [PubMed]

23. Sahoo, T.K.; Jena, P.K.; Nagar, N.; Patel, A.K.; Seshadri, S. In vitro evaluation of probiotic properties of lactic acid bacteria from the gut of Labeo tohita and Catla catla. Probiotics Antimicrob. Proteins 2015, 7, 126-136. [CrossRef] [PubMed]

24. Strøm, E.; Ringø, E. Changes in the bacterial composition of early developing cod, Gadus morhua (L.) larvae following inoculation of Lactobacillus plantarum into the water. In Physiology and Biochemical Aspects of Fish Development; Walther, B.T., Fyhn, H.J., Eds.; University of Bergen: Bergen, Norway, 1993; pp. 226-228.

25. Gobi, N.; Malaikozhundan, B.; Sekar, V.; Shanthi, S.; Vaseeharan, B.; Jayakumar, R.; Nazar, A.K. GFP tagged Vibrio parahaemolyticus Dahv2 infection and the protective effects of probiotic Bacillus licheniformis Dahb1 on the growth, immune and antioxidant responses in Pangasius hypophthalmus. Fish Shellfish Immunol. 2016, 52, $230-238$. [CrossRef] [PubMed]

26. Hai, N.V. The use of probiotics in aquaculture. J. Appl. Microbiol. 2015, 119, 917-935. [CrossRef] [PubMed]

27. Irianto, A.; Austin, B. Probiotics in aquaculture. J. Fish Dis. 2002, 25, 633-642. [CrossRef]

28. Das, S.; Ward, L.R.; Burke, C. Prospects of using marine actinobacteria as probiotics in aquaculture. Appl. Microbiol. Biotechnol. 2008, 81, 419-429. [CrossRef] [PubMed] 
29. Cordero, H.; Guardiola, F.A.; Tapia-Paniagua, S.T.; Cuesta, A.; Meseguer, J.; Balebona, M.C. Modulation of immunity and gut microbiota after dietary administration of alginate encapsulated Shewanella putrefaciens Pdp11 to gilthead seabream (Sparus aurata L.). Fish Shellfish Immunol. 2015, 45, 608-618. [CrossRef] [PubMed]

30. Guardiola, F.A.; Bahi, A.; Bakhrouf, A.; Esteban, M.Á. Effects of dietary supplementation with fenugreek seeds, alone or in combination with probiotics, on gilthead seabream (Sparus aurata L.) skin mucosal immunity. Fish Shellfish Immunol. 2017, 65, 169-178. [CrossRef] [PubMed]

31. Ringø, E.; Birkbeck, T.H.; Munro, P.D.; Vadstein, O.; Hjelmeland, K. The effect of early exposure to Vibrio Pelagius on the aerobic bacterial flora of turbot, Scophthalmus maximus (L.) larvae. J. Appl. Bacteriol. 1996, 81, 207-211. [CrossRef]

32. Ringø, E.; Vadstein, O. Colonization of Vibrio Pelagius and Aeromonas caviae in early developing turbot (Scophthalmus maximus L.) larvae. J. Appl. Microbiol. 1998, 84, 227-233. [CrossRef] [PubMed]

33. Ringø, E. Does Carnobacterium divergens isolated from Atlantic salmon, Salmo salar L., colonize the gut of early developing turbot, Scophthalmus maximus L., larvae? Aquac. Res. 1999, 30, 229-232. [CrossRef]

34. Park, Y.H.; Hwang, S.Y.; Hong, M.K.; Kwon, K.H. Use of antimicrobial agents in aquaculture. Rev. Sci. Tech. 2012, 31, 189-197. [CrossRef] [PubMed]

35. Moriarty, D.J.W. Control of luminous Vibrio species in penaeid aquaculture ponds. Aquaculture 1998, 164, 351-358. [CrossRef]

36. Skjermo, J.; Vadstein, O. Techniques for microbial control in the intensive rearing of marine larvae. Aquaculture 1999, 177, 333-343. [CrossRef]

37. LaPatra, S.E.; Fehringer, T.R.; Cain, K.D. A probiotic Enterobacter sp. provides significant protection against Flavobacterium psychrophilum in rainbow trout (Oncorhynchus mykiss) after injection by two different routes. Aquaculture 2014, 433, 361-366. [CrossRef]

38. Sveinsdottir, H.; Steinarsson, A.; Gudmundsdottir, A. Differential protein expression in early Atlantic cod larvae (Gadus morhua) in response to treatment with probiotic bacteria. Comp. Biochem. Physiol. 2009, 4, 249-254. [CrossRef] [PubMed]

39. Olafsen, J.A. Interactions between fish larvae and bacteria in marine aquaculture. Aquaculture 2001, 200, $223-247$. [CrossRef]

40. Olafsen, J.A.; Hansen, G.H. Intact antigen uptake in intestinal epithelial cells of marine fish larvae. J. Fish Biol. 1992, 40, 141-156. [CrossRef]

41. Skjermo, J.; Vadstein, O. Characterization of the bacterial flora of mass cultivated Brachionu splicatilis. Hydrobiologia 1993, 255, 185-191. [CrossRef]

42. Villamil, L.; Figueras, A.; Planas, M.; Novoa, B. Pediococcus acidilactici in the culture of turbot (Psettamaxima) larvae: Administration pathways. Aquaculture 2010, 307, 83-88. [CrossRef]

43. Wang, Y.B.; Tian, Z.Q.; Yao, J.T.; Li, W.F. Effects of probiotics, Enterococcus faecium, on tilapia (Oreochromis niloticus) growth performance and immune response. Aquaculture 2008, 277, 203-207. [CrossRef]

44. Ruangsri, J.; Lokesh, J.; Fernandes, J.M.O.; Kiron, V. Transcriptional regulation of antimicrobial peptides in mucosal tissues of Atlantic cod Gadus morhua L. in response to different stimuli. Aquac. Res. 2014, 45, 1893-1905. [CrossRef]

45. Shaheen, A.A.; Eissa, N.; Abou-ElGheit, E.N.; Yao, H.; Wang, H.P. Effect of probiotic on growth performance and growth-regulated genes in yellow perch (Perca flavescens). GJFAR 2014, 1, 1-15. [CrossRef]

46. Gupta, A.; Gupta, P.; Dhawan, A. Paenibacillus polymyxa as a water additive improved immune response of Cyprinus carpio and disease resistance against Aeromonas hydrophila. Aquac. Rep. 2016, 4, 86-92. [CrossRef]

47. Schaeck, M.; Reyes-López, F.E.; Vallejos-Vidal, E.; Van Cleemput, J.; Duchateau, L.; Van den Broeck, W.; Tort, L.; Decostere, A. Cellular and transcriptomic response to treatment with the probiotic candidate Vibrio lentus in gnotobiotic sea bass (Dicentrarchus labrax) larvae. Fish Shellfish Immunol. 2017, 63, 147-156. [CrossRef] [PubMed]

48. Liu, F.; Han, W. Reuse strategy of wastewater in prawn nursery by microbial remediation. Aquaculture 2004, 230, 281-296. [CrossRef]

49. Gross, A.; Abutbul, S.; Zilberg, D. Acute and chronic effects of nitrite on white shrimp, Litopenaeus vannamei, cultured in low-salinity brackish water. J. World Aquac. Soc. 2004, 35, 315-321. [CrossRef]

50. Su, Z.; Li, Y.; Pan, L.; Xue, F. An investigation on the immunoassays of an ammonia nitrogen-degrading bacterial strain in aquatic water. Aquaculture 2016, 450, 17-22. [CrossRef]

51. Liu, C.H.; Chen, J.C. Effect of ammonia on the immune response of white shrimp Litopenaeus vannamei and its susceptibility to Vibrio alginolyticus. Fish Shellfish Immunol. 2004, 16, 321-334. [CrossRef] 
52. Rodríguez-Ramos, T.; Espinosa, G.; Hernández-López, J.; Gollas-Galván, T.; Marrero, J.; Borrell, Y.; Alonso, M.E.; Becquer, U. Effects of Echerichia coli lipopolysaccharides and dissolved ammonia on immune response in southern white shrimp Litopenaeus schmitti. Aquaculture 2008, 274, 118-125. [CrossRef]

53. Crab, R.; Avnimelech, Y.; Defoirdt, T.; Bossier, P.; Verstraete, W. Nitrogen removal techniques in aquaculture for a sustainable production. Aquaculture 2007, 270, 1-14. [CrossRef]

54. Martins, C.I.M.; Eding, E.H.; Verdegem, M.C.J.; Heinsbroek, L.T.N.; Schneider, O.; Blancheton, J.P.; d'Orbcastel, E.R.; Verreth, J.A.J. New developments in recirculating aquaculture systems in Europe: A perspective on environmental sustainability. Aquac. Eng. 2010, 43, 83-93. [CrossRef]

55. Chun, S.J.; Cui, Y.; Ahn, C.Y.; Oh, H.M. Improving water quality using settleable microalgae Ettlia sp. and the bacterial community in freshwater recirculating aquaculture system Danio rerio. Water Res. 2018, 135, 112-121. [CrossRef] [PubMed]

56. Badiola, M.; Mendiola, D.; Bostock, J. Recirculating Aquaculture Systems (RAS) analysis: Main issues on management and future challenges. Aquac. Eng. 2012, 51, 26-35. [CrossRef]

57. Burford, M.A.; Thompson, P.J.; McIntosh, P.R.; Bauman, R.H.; Pearson, D.C. The contribution of flocculated material to shrimp (Litopenaeus vannamei) nutrition in a high-intensity, zero exchange system. Aquaculture 2004, 232, 525-537. [CrossRef]

58. López-Elías, J.A.; Moreno-Arias, A.; Miranda-Baeza, A.; Martínez-Córdova, L.R.; Rivas-Vega, M.E.; Márquez-Ríos, E. Proximate composition of bioflocs in culture systems containing hybrid red tilapia fed diets with varying levels of vegetable meal inclusion. N. Am. J. Aquac. 2015, 77, 102-109. [CrossRef]

59. Tacon, A.G.J.; Cody, J.J.; Conquest, L.D.; Divakaran, S.; Forster, I.P.; Decamp, O.E. Effect of culture system on the nutrition and growth performance of Pacific white shrimp Litopenaeus vannamei (Boone) fed different diets. Aquac. Nutr. 2002, 8, 121-137. [CrossRef]

60. Martínez-Córdova, L.R.; Martínez-Porchas, M.; Emerenciano, M.G.C.; Miranda-Baeza, A.; Gollas-Galván, T. From microbes to fish the next revolution in food production. Crit. Rev. Biotechnol. 2017, 37, 287-295. [CrossRef] [PubMed]

61. Moreno-Arias, A.; López-Elías, J.A.; Martínez-Córdova, L.R.; Ramírez-Suárez, J.C.; Carvallo-Ruiz, M.G.; García-Sánchez, M.E.; Miranda-Baeza, A. Effect of fishmeal replacement with a vegetable protein mixture on the amino acid and fatty acid profiles of diets, biofloc and shrimp cultured in BFT system. Aquaculture 2018, 483, 53-62. [CrossRef]

62. Aguilera-Rivera, D.; Prieto-Davó, A.; Escalante, K.; Chávez, C.; Cuzon, G.; Gaxiola, G. Probiotic effect of FLOC on Vibrios in the pacific white shrimp Litopenaeus vannamei. Aquaculture 2014, 424, 215-219. [CrossRef]

63. Arias-Moscoso, J.L.; Espinoza-Barrón, L.G.; Miranda-Baeza, A.; Rivas-Vega, M.E.; Nieves-Soto, M. Effect of commercial probiotics addition in a biofloc shrimp farm during the nursery phase in zero water exchange. Aquac. Rep. 2018, 11, 47-52. [CrossRef]

64. Banerjee, G.; Ray, A.K. The advancement of probiotics research and its application in fish farming industries. Res. Vet. Sci. 2017, 115, 66-77. [CrossRef] [PubMed]

65. Guo, X.; Chen, D.D.; Peng, K.S.; Cui, Z.W.; Zhang, X.J.; Li, S.; Zhang, Y.A. Identification and characterization of Bacillus subtilis from grass carp (Ctenopharyngodon idellus) for use as probiotic additives in aquatic feed. Fish Shellfish Immunol. 2016, 52, 74-84. [CrossRef] [PubMed]

66. Cha, J.H.; Rahimnejad, S.; Yang, S.Y.; Kim, K.W.; Lee, K.J. Evaluations of Bacillus spp. as dietary additives on growth performance, innate immunity and disease resistance of olive flounder (Paralichthys olivaceus) against Streptococcus iniae and as water additives. Aquaculture 2013, 402-403, 50-57. [CrossRef]

67. Balcazar, J.L.; de Blas, I.; Ruiz-Zarzuela, I.; Cunningham, D.; Vendrell, D.; Muzquiz, J.L. The role of probiotics in aquaculture. Vet. Microbiol. 2006, 114, 173-186. [CrossRef] [PubMed]

68. Zorriehzahra, M.J.; Torabi Delshad, S.; Adel, M.; Tiwari, R.; Karthik, K.; Dhama, K.; Lazado, C.C. Probiotics as beneficial microbes in aquaculture: An update on their multiple modes of action: A review. Vet. Quart. 2016, 1-16. [CrossRef] [PubMed]

69. Zhang, Q.H.; Feng, Y.H.; Wang, J.; Guo, J.; Zhang, Y.H.; Gao, J.Z.; Song, Z.F. Study on the characteristics of the ammonia-nitrogen and residual feeds degradation in aquatic water by Bacillus licheniformis. Acta Hydrobiol. Sin. 2011, 35, 498-503.

70. Jóźwiakowski, K.; Czernaś, K.; Szczurowska, A. Preliminary results of studies on the purification of water in a pond using the SCD Probiotics technology. Ecohydrol. Hydrobiol. 2009, 9, 307-312. [CrossRef] 
71. Banerjee, S.; Khatoon, H.; Shariff, M.; Yusoff, F.M. Enhancement of Penaeus monodon shrimp post larvae growth and survival without water exchange using marine Bacillus pumilus and periphytic microalgae. Fish. Sci. 2010, 76, 481-487. [CrossRef]

72. Aguirre-Guzman, G.; Lara-Flores, M.; Sanchez-Martinez, J.G.; Campa-Cordova, A.I.; Luna-Gonzalez, A. The use of probiotics in aquatic organisms: A review. Afr. J. Microbiol. Res. 2012, 2, 4854-4857. [CrossRef]

73. Verschuere, L.; Rombaut, G.; Sorgeloos, P.; Verstraete, W. Probiotic bacteria as biological control agents in aquaculture. Microbiol. Mol. Biol. Rev. 2000, 64, 655-671. [CrossRef] [PubMed]

74. Ibrahem, M.D. Evolution of probiotics in aquatic world: Potential effects, the current status in Egypt and recent prospective. J. Adv. Res. 2015, 6, 765-791. [CrossRef] [PubMed]

75. Irianto, A.; Austin, B. Use of dead probiotic cells to control furunculosis in rainbow trout, Oncorhynchus mykiss (Walbaum). J. Fish Dis. 2003, 26, 59-62. [CrossRef] [PubMed]

76. Kim, D.H.; Austin, B. Cytokine expression in leucocytes and gut cells of rainbow trout, Oncorhynchus mykiss Walbaum, induced by probiotics. Vet. Immunol. Immunopathol. 2006, 114, 297-304. [CrossRef] [PubMed]

77. Kim, D.H.; Austin, B. Innate immune responses in rainbow trout (Oncorhynchus mykiss, Walbaum) induced by probiotics. Fish Shellfish Immunol. 2006, 21, 513-524. [CrossRef] [PubMed]

78. Kumar, R.; Mukherjee, S.C.; Ranjan, R.; Nayak, S.K. Enhanced innate immune parameters in Labeo rohita (Ham.) following oral administration of Bacillus subtilis. Fish Shellfish Immunol. 2008, 24, 168-172. [CrossRef] [PubMed]

79. Nayak, S.K.; Swain, P.; Mukherjee, S.C. Effect of dietary supplementation of probiotic and vitamin C on the immune response of Indian major carp, Labeo rohita (Ham.). Fish Shellfish Immunol. 2007, 23, 892-896. [CrossRef] [PubMed]

80. Adams, C.A. The probiotic paradox: Live and dead cells are biological response modifiers. Nutr. Res. Rev. 2010, 23, 37-46. [CrossRef] [PubMed]

81. Akhter, N.; Wu, B.; Memon, A.M.; Mohsin, M. Probiotics and prebiotics associated with aquaculture: A review. Fish Shellfish Immunol. 2015, 45, 733-741. [CrossRef] [PubMed]

82. Widanarni; Tanbiyaskur. Application of probiotic, prebiotic and symbiotic for the control of Streptococcosis in Tilapia Oreochromis niloticus. Pak. J. Biol. Sci. 2015, 18, 59-66. [CrossRef]

83. Dimitroglou, A.; Merrifield, D.L.; Carnevali, O.; Picchietti, S.; Avella, M.; Daniels, C.; Güroy, D.; Davies, S.J. Microbial manipulations to improve fish health and production-A Mediterranean perspective. Fish Shellfish Immunol. 2011, 30, 1-16. [CrossRef] [PubMed]

84. Lazado, C.C.; Caipang, C.M.A. Atlantic cod in the dynamic probiotics research in aquaculture. Aquaculture 2014, 424-425, 53-62. [CrossRef]

85. Picchietti, S.; Fausto, A.M.; Randelli, E.; Carnevali, O.; Taddei, A.R.; Buonocore, F.; Scapigliati, G.; Abelli, L. Early treatment with Lactobacillus delbrueckii strain induces an increase in intestinal T-cells and granulocytes and modulates immune-related genes of larval Dicentrarchuslabrax (L.). Fish Shellfish Immunol. 2009, 26, 368-376. [CrossRef] [PubMed]

86. Picchietti, S.; Mazzini, M.; Taddei, A.R.; Renna, R.; Fausto, A.M.; Mulero, V.; Carnevali, O.; Cresci, A.; Abelli, L. Effects of administration of probiotic strains on GALT of larval gilthead sea bream: Immunohistochemical and ultrastructural studies. Fish Shellfish Immunol. 2007, 22, 57-67. [CrossRef] [PubMed]

87. Pirarat, N.; Pinpimai, K.; Endo, M.; Katagiri, T.; Ponpornpisit, A.; Chansue, N.; Maita, M. Modulation of intestinal morphology and immunity in nile tilapia (Oreochromis niloticus) by Lactobacillus rhamnosus GG. Res. Vet. Sci. 2011, 91, 92-97. [CrossRef] [PubMed]

88. Lazado, C.C.; Caipang, C.M.A. Mucosal immunity and probiotics in fish. Fish Shellfish Immunol. 2014, 39, 78-89. [CrossRef] [PubMed]

89. Ellis, A.E. Ontogeny of the immune system in teleost fish. In Fish Vaccination; Ellis, A.E., Ed.; Academic Press: London, UK, 1998; pp. 20-31.

90. Chantanachookhin, C.; Seikai, T.; Tanaka, M. Comparative study of the ontogeny of the lymphoid organs in three species of marine fish. Aquaculture 1991, 99, 143-155. [CrossRef]

91. Ottasen, O.H.; Olafsen, J.A. Effects on survival and mucous cell proliferation of Atlantic halibut, Hippoglossus hippoglossus L., larvae following microflora manipulation. Aquaculture 2000, 187, 225-238. [CrossRef]

92. Hatai, K.; Hoshiai, G. Mass mortality in cultured coho salmon (Oncorhynchus kisutch) due to Saprolagnia parasitica coker. J. Wildl. Dis. 1992, 28, 532-536. [CrossRef] [PubMed]

93. Liu, S.; Song, P.; Ou, R.; Fang, W.; Lin, M.; Ruan, J.; Yang, X.; Hu, K. Sequence analysis and typing of Saprolegnia strains isolated from freshwater fish from Southern Chinese regions. Aquac. Fish. 2017, 2, 227-233. [CrossRef] 
94. Lategan, M.J.; Gibson, L.F. Antagonistic activity of Aeromonas media strain A199 against Saprolegnia sp., an opportunistic pathogen of the eel, Anguilla australis Richardson. J. Fish Dis. 2003, 26, 147-153. [CrossRef] [PubMed]

95. Lategan, M.J.; Torpy, F.R.; Gibson, L.F. Biocontrol of saprolegniosis in silver perch Bidyanus bidyanus (Mitchell) by Aeromonas media strain A100. Aquaculture 2004, 235, 77-88. [CrossRef]

96. Lategan, M.J.; Torpy, F.R.; Gibson, L.F. Control of saprolegniosis in the eel Anguilla australis Richardson, by Aeromonas media strain 199. Aquaculture 2004, 2004, 19-27. [CrossRef]

97. Wesseling, W.; Wittka, S.; Kroll, S.; Soltmann, C.; Kegler, P.; Kunzmann, A.; Riss, H.W.; Lohmeyer, M. Functionalised ceramic spawning tiles with probiotic Pseudoalteromonas biofilms designed for clownfish aquaculture. Aquaculture 2015, 446, 57-66. [CrossRef]

98. Dawood, M.A.O.; Koshio, S.; Ishikawa, M.; Yokoyama, S. Interaction effects of dietary supplementation of heat-killed Lactobacillus plantarum and $\beta$-glucan on growth performance, digestibility and immune response of juvenile red sea bream, Pagrus major. Fish Shellfish Immunol. 2015, 45, 33-42. [CrossRef] [PubMed]

99. Hai, N.V. Research findings from the use of probiotics in tilapia aquaculture: A review. Fish Shellfish Immunol. 2015, 45, 592-597. [CrossRef] [PubMed]

100. Mandiki, S.N.M.; Milla, S.; Wang, N.; Blanchard, G.; Djonkack, T.; Tanascaux, S.; Kestemont, P. Effects of probiotic on growth parameters and immune defense in Eurasian perch Perca fluviatilis L. larvae under intensive culture conditions. Aquac. Res. 2011, 42, 693-703. [CrossRef]

101. Suzer, C.; Çoban, D.; OkanKamaci, H.; Saka, Ş.; Firat, K.; Otgucuoğlu, Ö.; Küçüksari, H. Lactobacillus spp. bacteria as probiotics in gilthead sea bream (Sparus aurata L.) larvae: Effects on growth performance and digestive enzyme activities. Aquaculture 2008, 280, 140-145. [CrossRef]

102. Lauzon, H.L.; Gudmundsdottir, S.; Steinarsson, A.; Oddgeirsson, M.; Petursdottir, S.K.; Reynisson, E.; Bjornsdottir, R.; Gudmundsdottir, B.K. Effects of bacterial treatment at early stages of Atlantic cod (Gadus morhua L.) on larval survival and development. J. Appl. Microbiol. 2010, 108, 624-632. [CrossRef] [PubMed]

103. Gatesoupe, F.J. Updating the importance of lactic acid bacteria in fish farming: Natural occurrence and probiotic treatments. J. Mol. Microbiol. Biotechnol. 2008, 14, 107-114. [CrossRef] [PubMed]

104. Chinabut, S.; Puttinaowarat, S. The choice of disease control strategies to secure international market access for aquaculture products. Dev. Biol. 2005, 121, 255-261.

105. Skjermo, J.; Bakke, I.; Dahle, S.W.; Vadstein, O. Probiotics strains introduced through live feed and rearing water have low colonizing success in developing Atlantic cod larvae. Aquaculture 2015, 438, 17-23. [CrossRef]

106. Widanarni, W.; Yuniasari, D.; Sukenda, S.; Ekasari, J. Nursery culture performance of Litopenaeus vannamei with probiotics addition and different $\mathrm{C} / \mathrm{N}$ ratio under laboratory condition. Hayati J. Biosci. 2010, 17, 115-119. [CrossRef]

107. Hostins, B.; Lra, G.; Decamp, O.; Cesar, D.E.; Wasielesky, W. Efficacy and variations in bacterial density in the gut of Litopenaeus vannamei reared in a BFT system and in clear water supplemented with a commercial probiotic mixture. Aquaculture 2017, 480, 58-64. [CrossRef]

108. Reyes-López, F.E.; Romeo, J.S.; Vallejos-Vidal, E.; Reyes-Cerpa, S.; Sandino, A.M.; Tort, L.; Mackenzie, S.; Imarai, M. Differential immune gene expression profiles in susceptible and resistant full-sibling families of Atlantic salmon (Salmo salar) challenged with infectious pancreatic necrosis virus (IPNV). Dev. Comp. Immunol. 2015, 53, $210-221$. [CrossRef] [PubMed]

109. Murray, H.M.; Lall, S.P.; Rajaselvam, R.; Boutilier, L.A.; Blanchard, B.; Flight, R.M.; Colombo, S.; Mohindra, V.; Douglas, S.E. A nutrigenomic analysis of intestinal response to partial soybean meal replacement in diets for juvenile Atlantic halibut, Hippoglossus hipoglossus, L. Aquaculure 2010, 298, 282-293. [CrossRef]

(C) 2018 by the authors. Licensee MDPI, Basel, Switzerland. This article is an open access article distributed under the terms and conditions of the Creative Commons Attribution (CC BY) license (http:/ / creativecommons.org/licenses/by/4.0/). 